\title{
Hubungan antara Faktor Risiko Demografi dan Klinis terhadap Kejadian Persalinan Spontan Preterm Dini dan Lanjut
}

\author{
Rahadyan Aji Sasongko, Jusuf Sulaeman Effendi, Udin Sabarudin, Edwin Armawan \\ Amillia Siddiq, Zulvayanti \\ Departemen Obstetri dan Ginekologi Fakultas Kedokteran Universitas Padjadjaran \\ Rumah Sakit Dr. Hasan Sadikin Bandung \\ Korespondensi: Rahadyan Aji Sasongko,Email: sasongko2005@gmail.com
}

\begin{abstract}
Abstrak
Tujuan: Persalinan preterm dini dan lanjut masih menjadi penyebab penting morbiditas dan mortalitas perinatal. Penelitian ini bertujuan untuk mengetahui karakteristik pasien, menganalisis hubungan faktor risiko demografi dan klinik dengan persalinan spontan preterm dini dan preterm lanjut periode Januari 2015-Desember 2016.

Metode: Penelitian secara potong lintang retrospektif dilaksanakan pada bulan April-Juni 2017 dengan sumber data rekam medis Rumah Sakit Hasan Sadikin.

Hasil: penelitian menunjukan insidensi persalinan preterm adalah 38,54\%. Terdapat hubungan signifikan dari faktor risiko pendidikan, jumlah perawatan antenatal, riwayat persalinan preterm, dan ketuban pecah dini terhadap kejadian persalinan spontan preterm dini dan preterm lanjut. Pendidikan SD meningkatkan kejadian persalinan preterm dini 2,3 kali, perawatan antenatal kurang dari 4 kali selama kehamilan meningkatkan kejadian persalinan preterm dini 1,6 kali, riwayat persalinan preterm sebelumnya meningkatkan kejadian persalinan preterm dini 1,9 kali. Ketuban pecah dini meningkatkan kejadian persalinan preterm lanjut 2,6 kali $(\mathrm{p}<0,05)$.

Kesimpulan: Terdapat hubungan antara tingkat pendidikan, jumlah perawatan antenatal, riwayat persalinan preterm, dan ketuban pecah dini, dengan persalinan spontan preterm dini dan preterm lanjut.
\end{abstract}

Kata kunci: Faktor demografi, faktor klinik, persalinan spontan preterm dini, persalinan spontan preterm lanjut

\section{Relation between Demographic and Clinical Risk Factors to the Occurrence of Spontaneous Early and Late Preterm Birth}

\begin{abstract}
Objective: Early and late preterm birth remains an important cause of perinatal morbidity and mortality. Various studies indicate the incidence of is influenced by demographic and clinical factors affecting baby's outcome. This study aims to analyze demographic and clinical factor's relations of spontaneous early and late preterm birth in Hasan Sadikin General Hospital, from January 2015 until December 2016.

Method: Retrospective-cross sectional was conducted in April until June 2017 from Hasan Sadikin General Hospital's medical record, collected from January 2015 to December 2016.

Results: Incidence of preterm birth from January 2015 until December 2016 was 38,54\%. There was significant relations of education, times of antenatal care, previous preterm birth, and premature rupture of membrane with spontaneous early and late preterm birth. Education level of elementary school increased the incidence of spontaneous early preterm birth 2.3 times, previous preterm birth increased the incidence of spontaneous early preterm birth 1.6 times, antenatal care less than 4 times increased the incidence of spontaneous early preterm birth 1.9 times. Premature rupture of membrane increased the incidence of spontaneous late preterm birth 2.6 times $(p<0.05$.

Conclusion: there is a relations between education, times of antenatal care, previous preterm birth, and premature rupture of membrane, with spontaneous early and late preterm birth.
\end{abstract}

Keywords: Demographic factors, clinical factors, preterm spontaneous early delivery, spontaneous late preterm delivery 


\section{Pendahuluan}

Kejadian persalinan preterm dini dan lanjut baik di negara maju maupun berkembang masih tinggi, dan merupakan masalah global sebagai penyebab kematian neonatal kedua terbanyak di dunia. ${ }^{1-6}$ Persalinan preterm dini dan lanjut juga merupakan penyebab utama cerebral palsy pada anak-anak yang bertahan hidup dan berhubungan dengan gangguan pertumbuhan lainnya. ${ }^{7-9}$ Tingginya morbiditas dan mortalitas perinatal pada persalinan preterm, terutama persalinan preterm dini, menunjukan masih banyak hal yang perlu diketahui mengenai persalinan preterm, terutama menyangkut identifikasi faktor risiko untuk menentukan kelompok risiko tinggi dan memperbaiki pelayanan. Terdapat beberapa faktor yang berperan pada terjadinya proses persalinan preterm, yaitu: idiopatik, iatrogenik, sosio demografik, faktor ibu, penyakit medis dan keadaan kehamilan, infeksi dan inflamasi, serta faktor genetik. ${ }^{10-12}$

Secara patogenesis, persalinan preterm dini diduga disebabkan oleh inflamasi akut plasenta, sedangkan persalinan preterm lanjut disebabkan oleh inflamasi kronis plasenta.13,14 Pengelolaan persalinan preterm dini dan preterm lanjut secara rasional dimulai dari tindakan untuk menghilangkan faktor risiko. Bila risiko persalinan preterm dini dikenali lebih awal, kemungkinan komplikasi persalinan preterm, terutama persalinan preterm dini, dapat dikurangi dan dapat dicegah. Penelitian di beberapa negara menunjukan perbedaan faktor risiko persalinan preterm dini dan preterm lanjut. ${ }^{6,10,15}$ Melalui data rekam medis dari Rumah Sakit Hasan Sadikin Bandung, dilakukan analisis faktor risiko yang berperan pada persalinan spontan preterm dini dan lanjut, yang selama ini belum pernah dilakukan di Indonesia dengan tujuan untuk menganalisis hubungan faktor risiko demografi dan faktor klinis dengan persalinan spontan preterm dini dan preterm lanjut di Rumah Sakit Hasan Sadikin
Bandung periode Januari 2015-Desember 2016.

\section{Metode}

Bahan penelitian diperoleh dari data rekam medis Rumah Sakit Dr. Hasan Sadikin Bandung periode 1 Januari 2015-31 Desember 2016. Metode penelitian yang digunakan adalah analitik komparatif potong lintang (cross sectional) dengan pendekatan retrospektif. Penelitian ini merupakan hospital based population study yang bersifat analitik observasional. Untuk melihat distribusi frekuensi serta persentase dari berbagai variabel yang diteliti, baik variabel bebas (faktor demografi dan faktor klinik) maupun variabel terikat (persalinan preterm dini dan persalinan preterm lanjut) digunakan analisis deskriptif. Analisis statistik untuk data kategorik dilakukan dengan uji Chisquare atau dengan alternatif uji Exact Fisher dan uji Kolmogorov Smirnov serta uji regresi logistic biner Nilai $\mathrm{p}<0,05$ dianggap bermakna statistik. Data yang diperoleh dicatat dalam formulir khusus kemudian diolah melalui program SPSS versi 23.0 for Windows.

\section{Hasil}

Penelitian ini dilakukan selama bulan April hingga Juni 2017 di Departemen Obstetri dan Ginekologi Rumah Sakit Dr. Hasan Sadikin Bandung. Subjek penelitian tersebut adalah kasus persalinan preterm dini dan lanjut yang terjadi secara spontan di Rumah Sakit Dr. Hasan Sadikin Bandung pada Januari 2015 hingga Desember 2016. Dari subjek penelitian tersebut dikumpulkan seluruh data, kemudian dilakukan pengolahan data meliputi proses editing, entry data pada program komputer, dan cleaning data keseluruhan sehingga siap untuk dilakukan analisis lebih lanjut. Seluruh analisis data dilakukan dengan menggunakan program SPSS for windows versi 23.0. 
Tabel 1 Insidensi Persalinan Preterm di Rumah Sakit Dr. Hasan Sadikin periode Januari 2015-Desember 2016

\begin{tabular}{lcc}
\hline \multicolumn{1}{c}{ Persalinan } & $\mathbf{N}$ & \% \\
\hline Persalinan Preterm & 1.255 & 38,54 \\
Persalinan Aterm & 2.001 & 61,46 \\
Total & 3.256 & 100 \\
\hline
\end{tabular}

Tabel 1 menunjukan insidensi persalinan preterm di Rumah Sakit Hasan Sadikin Bandung pada periode Januari 2015Desember 2016. Dari total 3.256 persalinan, angka kejadian persalinan preterm sebanyak 1.255 kasus, dengan insidensi 38,54\%. Dari total persalinan preterm, terdapat 773 kasus persalinan preterm spontan $(61,59 \%)$, dan 482 kasus persalinan preterm iatrogenik $(38,41 \%)$.

Tabel 2 Distribusi Persalinan Preterm Berdasarkan Tipe Persalinan di Rumah Sakit Dr. Hasan Sadikin Periode Januari 2015Desember 2016

\begin{tabular}{lcc}
\hline Tipe Persalinan & N & \% \\
\hline Persalinan Preterm Spontan & 773 & 61,59 \\
Persalinan Preterm Iatrogenik & 482 & 38,41 \\
Total & 1.255 & 100 \\
\hline
\end{tabular}

Tabel 3 Distribusi Persalinan Preterm Spontan berdasarkan Waktu Kejadian Persalinan di Rumah Sakit Dr. Hasan Sadikin Periode Januari 2015-Desember 2016

\begin{tabular}{lcc}
\hline Persalinan Preterm & N & \% \\
\hline Persalinan Preterm Dini & 462 & 59,77 \\
Persalinan Preterm Lanjut & 311 & 40,23 \\
Total & 773 & 100 \\
\hline
\end{tabular}

Berdasarkan usia kehamilan dari 773 kasus persalinan preterm spontan, 462 kasus merupakan persalinan preterm dini $(59,77 \%)$ dan 311 kasus merupakan persalinan preterm lanjut (40,23\%) seperti yang ditunjukan pada Tabel 3. Dengan jumlah persalinan 3.256 selama periode Januari 2015-Desember 2016, maka angka kejadian persalinan spontan preterm dini adalah $14,19 \%$ dan angka kejadian persalinan spontan preterm lanjut adalah 9,55\%.

Faktor risiko yang menunjukkan perbedaan signifikan antara persalinan spontan preterm dini dan preterm lanjut adalah pendidikan terakhir, perawatan antenatal, riwayat persalinan preterm, dan ketuban pecah dini saat persalinan (Tabel 4). Pada tingkat pendidikan terakhir, perbedaan persentase terbesar kasus persalinan preterm dini dan lanjut terjadi pada tingkat pendidikan SD, yaitu 95 (69,9\%) kasus persalinan preterm dini dan $40(30,1 \%)$ kasus persalinan preterm lanjut.

Pada riwayat perawatan antenatal, jumlah kasus persalinan preterm spontan terbanyak terjadi pada perawatan antenatal $\geq 4$ kali selama kehamilan, yaitu 656 kasus, terdiri dari $381(58,1 \%)$ kasus persalinan preterm dini dan $275(41,9 \%)$ kasus persalinan preterm lanjut. Akan tetapi perbedaan persentase terbesar terdapat pada perawatan antenatal $<4$ kali selama kehamilan, yaitu 81 $(69,2 \%)$ kasus persalinan preterm dini dan 36 $(30,8 \%)$ kasus persalinan preterm lanjut.

Pada riwayat persalinan preterm sebelumnya, terdapat 55 atau $72,4 \%$ kasus persalinan preterm dini, dan 21 kasus atau $27,6 \%$ kasus persalinan preterm lanjut. Pada riwayat ketuban pecah dini, terdapat 22 atau $61,1 \%$ kasus persalinan preterm lanjut, dan 14 kasus atau 38,9\% kasus persalinan preterm dini. Tabel 5 menyajikan hubungan faktor risiko demografi dan klinik dengan persalinan spontan preterm dini di Rumah Sakit Dr. Hasan Sadikin Bandung periode Januari 2015-Desember 2016, dengan hasil bermakna pada beberapa faktor, yaitu pendidikan, SD meningkatkan insidensi 
Tabel 4 Perbedaan faktor risiko demografi dan klinik pada persalinan spontan preterm dini dan lanjut di Rumah Sakit Hasan Sadikin Bandung periode Januari 2015-Desember 2016

\begin{tabular}{|c|c|c|c|c|c|}
\hline \multirow[t]{2}{*}{ Variabel } & \multicolumn{2}{|c|}{ Preterm Dini } & \multicolumn{2}{|c|}{ Preterm Lanjut } & \multirow{2}{*}{$\begin{array}{c}\mathrm{X}^{2} \\
\text { Nilai } \mathrm{p}^{*}\end{array}$} \\
\hline & $\mathrm{N}$ & $\%$ & $\mathrm{~N}$ & $\%$ & \\
\hline Usia (tahun) & & & & & 0,106 \\
\hline$<20$ & 85 & 68,0 & 40 & 32,0 & \\
\hline $20-35$ & 304 & 57,7 & 223 & 42,3 & \\
\hline$>35$ & 73 & 60,3 & 48 & 39,7 & \\
\hline Pendidikan & & & & & 0,031 \\
\hline $\mathrm{SD}$ & 95 & 69,9 & 41 & 30,1 & \\
\hline SMP & 144 & 58,8 & 101 & 41,2 & \\
\hline SMA & 176 & 58,7 & 124 & 41,3 & \\
\hline $\mathrm{Ak} / \mathrm{PT}$ & 47 & 51,1 & 45 & 48,9 & \\
\hline Pekerjaan & & & & & 0,918 \\
\hline Tidak bekerja & 272 & 59,5 & 185 & 40,5 & \\
\hline PNS & 11 & 61,1 & 7 & 38,9 & \\
\hline Karyawan swasta & 153 & 59,3 & 105 & 40,7 & \\
\hline Wiraswasta & 26 & 65,0 & 14 & 35,0 & \\
\hline Paritas & & & & & 0,434 \\
\hline Primipara & 191 & 57,9 & 139 & 42,1 & \\
\hline Multipara & 259 & 61,7 & 161 & 38,3 & \\
\hline Grande multipara & 12 & 52,2 & 11 & 47,8 & \\
\hline Perawatan Antenatal & & & & & 0,023 \\
\hline$<4$ kali & 81 & 69,2 & 36 & 30,8 & \\
\hline$\geq 4$ kali & 381 & 58,1 & 275 & 41,9 & \\
\hline Riwayat Persalinan $\mathrm{P}_{1}$ & term & & & & 0,018 \\
\hline $\mathrm{Ya}$ & 55 & 72,4 & 21 & 27,6 & \\
\hline Tidak & 407 & 58,4 & 290 & 41,6 & \\
\hline Riwayat Abortus & & & & & 0,363 \\
\hline $\mathrm{Ya}$ & 59 & 64,1 & 33 & 35,9 & \\
\hline Tidak & 403 & 59,2 & 278 & 40,8 & \\
\hline Anemia & & & & & 0,114 \\
\hline $\mathrm{Ya}$ & 113 & 55,1 & 92 & 44,9 & \\
\hline Tidak & 349 & 61,4 & 219 & 38,6 & \\
\hline Ketuban Pecah Dini & & & & & 0,009 \\
\hline $\mathrm{Ya}$ & 14 & 38,9 & 22 & 61,1 & \\
\hline Tidak & 448 & 60,8 & 289 & 39,2 & \\
\hline Diabetes & & & & & 0,350 \\
\hline $\mathrm{Ya}$ & 1 & 33,3 & 2 & 66,7 & \\
\hline Tidak & 461 & 59,9 & 309 & 40,1 & \\
\hline Kelainan Tiroid & & & & & 0,069 \\
\hline
\end{tabular}


Lanjutan Tabel 4

\begin{tabular}{lrrrrr}
\hline Variable & \multicolumn{2}{c}{ Preterm Dini } & \multicolumn{2}{c}{ Preterm Lanjut } & $\mathrm{X}^{2}$ \\
& $\mathrm{~N}$ & \multicolumn{1}{c}{$\%$} & \multicolumn{1}{c}{$\mathrm{N}$} & \multicolumn{1}{c}{$\%$} & Nilai $^{*}$ \\
\hline Ya & 1 & 20,0 & 4 & 80,0 & \\
Tidak & 461 & 60,0 & 307 & 40,0 & \\
\hline
\end{tabular}

Keterangan : *dihitung berdasarkan uji Chi-kuadrat

Tabel 5 Hubungan Faktor Risiko Demografi dan Klinik pada Persalinan Spontan Preterm Dini di Rumah Sakit Dr. Hasan Sadikin Bandung periode Januari 2015-Desember 2016

\begin{tabular}{|c|c|c|c|c|c|}
\hline \multirow{2}{*}{\multicolumn{2}{|c|}{ Variabel }} & \multirow{2}{*}{ Nilai $\mathrm{p}$} & \multirow{2}{*}{$\begin{array}{c}\text { Adjusted } \\
\text { OR }\end{array}$} & \multicolumn{2}{|c|}{ IK $95 \%$} \\
\hline & & & & Min & $\operatorname{Max}$ \\
\hline \multicolumn{6}{|c|}{ I Model Awal } \\
\hline \multicolumn{6}{|l|}{ Usia } \\
\hline - & $<20$ tahun & 0,051 & 1,537 & 0,999 & 2,365 \\
\hline- & 20-35 tahun & - & - & - & - \\
\hline - & $>35$ tahun & 0,800 & 0,947 & 0,622 & 1,443 \\
\hline \multicolumn{6}{|c|}{ Pendidikan } \\
\hline & $\mathrm{SD}$ & 0,007 & 2,177 & 1,238 & 3,828 \\
\hline- & SMP & 0,375 & 1,254 & 0,760 & 2,070 \\
\hline - & SMA & 0,288 & 1,299 & 0,802 & 2,104 \\
\hline- & Akademi/PT & - & - & - & - \\
\hline Perav & $\tan$ Antenatal & 0,027 & 1,629 & 1,057 & 2,510 \\
\hline Riwa & tt Persalinan Preterm & 0,008 & 2,081 & 1,214 & 3,569 \\
\hline Anen & & 0,067 & 0,732 & 0,525 & 1,021 \\
\hline Ketul & n Pecah Dini & 0,005 & 0,363 & 0,178 & 0,739 \\
\hline Kelai & an Tiroid & 0,098 & 0,154 & 0,017 & 1,408 \\
\hline \multicolumn{6}{|c|}{ II Model Akhir } \\
\hline \multicolumn{6}{|c|}{ Pendidikan } \\
\hline - & $\mathrm{SD}$ & 0,003 & 2,321 & 1,328 & 4,055 \\
\hline - & SMP & 0,225 & 1,354 & 0,830 & 2,209 \\
\hline - & SMA & 0,232 & 1,337 & 0,830 & 2,154 \\
\hline - & Akademi/PT & - & - & - & - \\
\hline Perav & $\tan$ Antenatal & 0,032 & 1,597 & 1,041 & 2,451 \\
\hline Riwa & tt Persalinan Preterm & 0,012 & 1,986 & 1,164 & 3,388 \\
\hline Ketub & n Pecah Dini & 0,008 & 0,388 & 0,192 & 0,782 \\
\hline
\end{tabular}

Keterangan : Uji statistik dihitung berdasarkan uji regresi logistik ganda (uji Wald), akurasi model 60,3\% OR : Odd Ratio IK : Indeks Kepercayaan 
Tabel 6 Hubungan Faktor Risiko Demografi dan Klinik pada Persalinan Spontan preterm Lanjut di Rumah Sakit Dr. Hasan Sadikin periode Januari 2015-Desember 2016

\begin{tabular}{|c|c|c|c|c|c|}
\hline \multirow{2}{*}{\multicolumn{2}{|c|}{ Variabel }} & \multirow{2}{*}{ Nilai $\mathrm{p}$} & \multirow{2}{*}{$\begin{array}{l}\text { Adjusted } \\
\text { OR }\end{array}$} & \multicolumn{2}{|c|}{ IK $95 \%$} \\
\hline & & & & Min & Max \\
\hline \multicolumn{6}{|c|}{ I Model Awal } \\
\hline \multicolumn{6}{|l|}{ Usia } \\
\hline- & $<20$ tahun & 0,051 & 0,651 & 0,423 & 1,001 \\
\hline - & 20-35 tahun & - & - & - & - \\
\hline- & $>35$ tahun & 0,800 & 1,056 & 0,693 & 1,609 \\
\hline \multicolumn{6}{|c|}{ Pendidikan } \\
\hline- & $\mathrm{SD}$ & 0,007 & 0,459 & 0,261 & 0,808 \\
\hline- & SMP & 0,375 & 0,797 & 0,483 & 1,316 \\
\hline- & SMA & 0,288 & 0,770 & 0,475 & 1,247 \\
\hline- & Akademi/PT & - & - & - & - \\
\hline Peraw & an Antenatal & 0,027 & 0,614 & 0,398 & 0,946 \\
\hline Riway & Persalinan Preterm & 0,008 & 0,480 & 0,280 & 0,824 \\
\hline Anem & & 0,067 & 1,365 & 0,979 & 1,904 \\
\hline Ketub & Pecah Dini & 0,005 & 2,754 & 1,352 & 5,610 \\
\hline Kelai & n Tiroid & 0,098 & 6,474 & 0,710 & 59,020 \\
\hline \multicolumn{6}{|c|}{ II Model Akhir } \\
\hline \multicolumn{6}{|c|}{ Pendidikan } \\
\hline- & $\mathrm{SD}$ & 0,003 & 0,431 & 0,247 & 0,753 \\
\hline- & SMP & 0,225 & 0,739 & 0,453 & 1,205 \\
\hline- & SMA & 0,232 & 0,748 & 0,464 & 1,204 \\
\hline- & Akademi/PT & - & - & - & - \\
\hline Peraw & an Antenatal & 0,032 & 0,626 & 0,408 & 0,961 \\
\hline Riway & Persalinan Preterm & 0,012 & 0,503 & 0,295 & 0,859 \\
\hline Ketub & Pecah Dini & 0,008 & 2,579 & 1,279 & 5,202 \\
\hline
\end{tabular}

Keterangan : Uji statistik dihitung berdasarkan uji regresi logistik ganda (uji Wald), akurasi model 60,3\%

OR : Odd Ratio

IK : Indeks Kepercayaan

riwayat perawatan antenatal, dan riwayat kehamilan preterm sebelumnya. Tingkat pendidikan persalinan spontan preterm dini 2,3 kali, perawatan antenatal kurang dari 4 kali selama kehamilan meningkatkan insidensi persalinan spontan preterm dini 1,6 kali, riwayat persalinan preterm sebelumnya meningkatkan insidensi persalinan spontan preterm dini 1,9 kali. Uji statistik tersebut menunjukkan nilai $\mathrm{p}$ sebesar 0,003 sampai 0,032 , lebih kecil dari 0,05, artinya signifikan atau bermakna secara statistik, atau terdapat korelasi bermakna antara faktor pendidikan, riwayat perawatan antenatal, dan riwayat kehamilan preterm sebelumnya dengan persalinan spontan preterm dini.

Tabel 6 menyajikan hubungan faktor risiko demografi dan klinik dengan persalinan spontan preterm lanjut di Rumah Sakit Dr. Hasan Sadikin Bandung periode Januari 2015-Desember 2016, dengan hasil bermakna pada riwayat ketuban pecah dini. Ketuban pecah dini meningkatkan insidensi persalinan spontan preterm lanjut 2,6 kali. Uji 
statistik tersebut menunjukan nilai $\mathrm{p}$ sebesar 0,008 artinya signifikan atau bermakna secara statistik, atau terdapat korelasi bermakna antara ketuban pecah dini dengan persalinan spontan preterm lanjut.

\section{Pembahasan}

Dari tabel hasil penelitian tampak bahwa sebagian besar ibu bersalin berada pada rentang usia $20-35$ tahun. Hal ini diasosiasikan sebagai salah satu wujud nyata piramida penduduk Indonesia yang berbentuk ekspansif dengan mayoritas penduduk adalah usia muda dan angka kelahiran yang tinggi.

Hasil uji analisis menunjukkan bahwa tidak terdapat perbedaan bermakna antara umur ibu dengan persalinan preterm dini dibandingkan dengan persalinan preterm lanjut. Pada semua tingkatan usia, kasus persalinan preterm dini lebih banyak dibandingkan dengan kasus persalinan preterm lanjut, namun pada usia $<20$ tahun, kasus persalinan preterm dini dan preterm lanjut memiliki perbedaan persentase terbesar. Ibu hamil usia muda cenderung memiliki psikologis belum matang, belum siap menjadi ibu dan menerima kehamilannya sehingga memicu terjadinya komplikasi obstetri., ${ }^{32,15}$ Seiring bertambahnya usia, risiko komplikasi kehamilan dan kelahiran semakin meningkat, namun masalah psikologis kehamilan dapat diatasi dengan lebih mudah oleh wanita hamil berusia tua. Para wanita ini biasanya memiliki pendidikan yang lebih baik, mencari pendapatan lebih tinggi daripada wanita berusia muda.

Pendidikan, kemiskinan dan akses terhadap pelayanan kesehatan merupakan hal yang tidak terpisahkan. Pendidikan tinggi membuat ibu mampu memanfaatkan dunia modern yaitu pengetahuan tentang fasilitas dan perawatan kesehatan modern serta mampu berkomunikasi dengan tenaga kesehatan. Pengetahuan tentang pentingnya pemanfaatan fasilitas kesehatan dan manfaatnya akan mempengaruhi perilaku dalam mengaksesnya. Wanita berpendidikan lebih rendah cenderung kurang memperhatikan kesehatan diri dan keluarganya, kurang memahami kegawatdaruratan kehamilan dan persalinan dan tingkat independensi dalam mengambil keputusan rendah. Hal ini mengakibatkan pemanfaatan fasilitas kesehatan yang menjadi kurang. Hasil penelitian menunjukkan bahwa tingkat pendidikan ibu yang rendah, yaitu tingkat sekolah dasar, berisiko lebih tinggi terhadap kejadian persalinan preterm dini, sejalan dengan penelitian yang menyebutkan bahwa persalinan preterm dini lebih banyak terjadi pada ibu dengan pendidikan rendah. ${ }^{4,6,15}$

Peluang kesehatan seseorang sangat dipengaruhi oleh kondisi sosial ekonomi. Pendidikan merupakan salah satu faktor penentu yang penting terhadap kesehatan. Tingginya tingkat pendidikan membantu meningkatkan kesejahteraan ekonomi. Untuk individu, pengetahuan dan kemampuan soaial dan personal yang didapat melalui pendidikan membantu individu untuk mengakses dan menggunakan informasi dan fasilitas kesehatan untuk menjaga dan meningkatkan kesehatan diri sendiri dan keluarganya.

Penelitian membuktikan bahwa ibu dengan tingkat pendidikan lebih tinggi menunjukkan perilaku kesehatan yang lebih baik dan lebih sedikit meniru kebiasaan yang tidak sehat. Ibu dengan tingkat pendidikan lebih tinggi menunjukkan pengetahuan lebih baik akan kondisi kesehatan dan pengobatan mereka, serta memiliki kemampuan lebih baik dalam memelihara kesehatan diri.

Pendidikan yang rendah juga dapat menjadi penyebab perilaku pasien enggan melakukan perawatan antenatal. Pada penelitian ini, perawatan antenatal kurang dari 4 kali selama kehamilan memiliki hubungan signifikan terhadap kejadian preterm dini. Hasil ini serupa dengan 
penelitian yang dilakukan oleh Hidayat dkk. yang menunjukan perawatan antenatal kurang dari 4 kali selama kehamilan meningkatkan persalinan preterm. ${ }^{16}$ Rekomendasi WHO menyebutkan bahwa minimal perawatan antenatal adalah 4 kali, sekali pada trimester pertama, sekali pada trimester kedua, dan dua kali pada trimester ketiga. ${ }^{4}$ Kurangnya perawatan antenatal menyebabkan tidak terdeteksinya risiko maupun tanda awal persalinan preterm sehingga meningkatkan angka kejadian persalinan preterm dini.

Pada penelitian ini, riwayat persalinan preterm sebelumnya meningkatkan risiko persalinan preterm dini. Pada pasien dengan persalinan preterm dini dengan riwayat persalinan preterm berulang memiliki faktor risiko berupa inkompetensi serviks. Definisi terkini mengenai inkompetensi serviks yaitu terjadinya pemendekan panjang serviks $<25$ $\mathrm{mm}$ melalui pemeriksaan ultrasonografi transvaginal pada usia kehamilan $<34$ minggu. Inkompetensi serviks sebagai penyebab berulangnya persalinan preterm dini dapat disebabkan berbagai proses, yaitu infeksi, inflamasi, efek hormon lokal maupun sistemik, atau bahkan predisposisi genetik. Penanganan inkompetensi serviks dengan cerclage diharapkan dapat menekan angka kejadian persalinan preterm dini berulang. ${ }^{7,11,17}$

Terdapat penelitian yang menjelaskan faktor genetik penyebab persalinan preterm dini pada pasien yang memiliki riwayat persalinan preterm sebelumnya. Pada penelitian yang dilakukan oleh Manuck et.al, terdapat perbedaan allele pada gen pasien dengan riwayat persalinan preterm berulang. Gen yang memiliki perbedaan ini berperan dalam jalur sintesis oksida nitrat sebagai penyebab persalinan preterm. ${ }^{18}$

Variasi genetik sangat berperan sebagai faktor risiko persalinan preterm dini. Patogenesis persalinan preterm yang disebabkan respon inflamasi maternal dipengaruhi oleh variasi genetik tersebut.
Beberapa kondisi polimorfisme yang dihubungkan dengan persalinan preterm dini adalah polimorfisme pada tumor necrosis-alpha (TNFA), interleukin-1, interleukin-6, type 1 insulin-like growth factor receptor (IGFIR), dan tissue inhibitor of metalloproteinase-2 (TIMP2). Polimorfisme pada gen fms-related tyrosine kinase 1 (FLT1) secara signifikan berperan dalan terjadinya persalinan preterm dini. ${ }^{19}$

Pada penelitian ini, anemia lebih banyak ditemukan pada pasien dengan persalinan preterm dini, namun tidak memiliki hubungan yang signifikan. Hal ini sejalan dengan beberapa penelitian yang dilakukan di Cina yang mengemukakan bahwa tidak terdapat hubungan antara anemia dengan persalinan preterm. Penelitian terakhir melaporkan bahwa anemia berat (kadar hemoglobin $<7 \mathrm{~g}$ / dl) pada trimester ketiga berhubungan dengan persalinan preterm. ${ }^{20-22}$

Hal yang menarik pada penelitian ini adalah faktor klinis lebih banyak berperan dalam meningkatkan risiko kejadian persalinan preterm lanjut dibandingkan dengan persalinan preterm dini. Pada penelitian ini ketuban pecah dini, diabetes dalam kehamilan, dan kelainan tiroid lebih sering ditemukan pada persalinan preterm lanjut, walaupun hanya ketuban pecah dini yang memiliki hubungan yang signifikan terhadap terjadinya persalinan preterm lanjut.

Beberapa penelitian mengungkapkan bahwa inflamasi kronis pada plasenta merupakan penyebab terjadinya persalinan preterm lanjut. Penelitian yang dilakukan oleh J.Lee et al. menunjukan bahwa inflamasi kronis plasenta lebih banyak ditemukan pada persalinan preterm lanjut. Sebaliknya, inflamasi akut plasenta lebih banyak ditemukan pada persalinan preterm dini. ${ }^{13}$

Inflamasi kronis plasenta merupakan proses patologi yang ditandai dengan infiltasi limfosit, sel plasma, dan histiosit yang dapat terjadi pada vili, membran korioamnion, lempeng korion, atau lempeng basalis pada 
plasenta. Lesi inflamasi kronis pada plasenta dapatdisebabkan olehinfeksi mikroorganisme (bakteri, virus, atau parasit), namun sebagian besar kasus tidak diketahui penyebabnya. Terdapat beberapa penelitian yang menduga bahwa penolakan maternal anti-fetal memliki peran penting pada patogenesis inflamasi kronis plasenta. ${ }^{13}$

Pada penelitian ini, ketuban pecah dini sebagai faktor risiko persalinan preterm memiliki hubungan signifikan terhadap terjadinya persalinan preterm lanjut. Dari beberapa penelitian, ketuban pecah dini merupakan penyebab terbanyak kedua, setelah idiopatik, sebagai penyebab persalinan preterm lanjut. Telah banyak penelitian yang menjelaskan teori terjadinya ketuban pecah dini, dengan mekanisme akhirnya adalah kelemahan pada membrane amniokorion sehingga menyebabkan robekan. Kelemahan ini diakibatkan degradasi matriks ekstraseluler yang diregulasi pleh berbagai MMP (MMP1,2,3, dan 9) yang diaktivasi oleh proses infeksi atau inflamasi. ${ }^{7,11}$ Infeksi mikoplasma genital dapat menyebabkan inflamasi kronis pada saluran urogenital dan membrane amnion. Ureaplasma spp. Dapat menginfeksi kantung amnion pada awal kehamilan tanpa menyebabkan pecahnya selaput amnion, sehingga terjadi korioamnionitis kronis disertai respon inflamasi. Penelitian in vitro menunjukan bahwa Ureaplasma spp. Menstimulasi makrofag untuk menghasilkan sitokin proinflamasi seperti interleukin-6 dan tumor necrosis factor-alpha. ${ }^{7,11}$

Korioamnionitis kronis juga dapat terjadi pada pasien dengan diabetes dalam kehamilan, terutama pasien dengan kontrol diabetes yang buruk. Pada pasien ini, persalinan preterm lanjut diduga disebabkan oleh infeksi kronis pada saluran urogenital sebagai akibat dari meningkatnya kadar gula darah. Penyebab lain dari persalinan preterm lanjut pada pasien dengan diabetes dalam kehamilan adalah akibat dari terjadinya polihidramnion. Sekitar 15\% pasien dengan diabetes mengalami polihidramnion. Pada pasien dengan diabetes yang tidak terkontrol, jumlah cairan amnion 500 cc lebih banyak dibandingkan dengan pasien dengan diabetes yang terkontrol. Penyebab terjadinya polihidramnion pada pasien diabetes adalah kondisi maternal hipergikemia yang menyebabkan terjadinya fetal hiperglikemia dan berujung ada diuresis osmotik. ${ }^{23}$

Pada pasien dengan kelainan tiroid, proses inflamasi yang menyebabkan persalinan preterm disebabkan oleh antibodi tiroid yang menyebabkan abnormalitas dari sel $\mathrm{T}$, hiperaktifitas dan peningkatan sel natural killer (NK), aktifasi sel poliklonal B dan autoantibodi nonspesifik, serta defisiensi vitamin D. Pada beberapa penelitian, proses inflamasi ini terjadi pada awal kehamilan dan mengakibatkan keguguran atau persalinan preterm dini. Berbeda dengan penelitian ini yang menunjukan kelainan tiroid lebih banyak terjadi pada persalinan preterm lanjut, walaupun tidak memiliki hubungan yang signifikan. ${ }^{24,25}$ Penelitian ini mempunyai keterbatasan yang dapat mempengaruhi hasil penelitian. Keterbatasan dalam penelitian ini pengambilan data dilakukan melalui data rekam medis sehingga variabel penelitian terbatas. Beberapa variabel yang mempengaruhi persalinan preterm tidak terdapat di rekam medis, seperti tingkat kemiskinan, tingkat stres pasien, atau kebiasaan merokok. Data akan lebih memadai apabila dilengkapi informasi dari kuesioner. Simpulan, dari hasil penelitian dapat disimpulkan bahwa terdapat hubungan antara faktor risiko demografi dan klinik dengan persalinan spontan preterm dini dan preterm lanjut di Rumah Sakit Hasan Sadikin Bandung periode Januari 2015 - Desember 2016. Perlu penanganan khusus oleh tenaga kesehatan bila saat antenatal care terdapat faktor-faktor risiko ibu hamil terutama; 1) pendidikan SD, 2) perawatan antenatal kurang dari 4 kali, 3) riwayat persalinan preterm sebelumnya, dan 4) ketuban pecah dini. Perlu 
penelitian lanjutan dengan rancangan kohort prospektif, sehingga data yang didapatkan dapat menghasilkan sistim skoring untuk memprediksi kejadian persalinan preterm dini dan lanjut.

\section{Daftar Pustaka}

1. Cunningham $\mathrm{FG}$, Leveno $\mathrm{K}$, Bloom $\mathrm{S}$, Spong C, Dashe J, Hoffmann B, et al. Preterm Birth. Williams Obstetrics. Edisi ke- 24. New York: McGraw-Hills; 2014. hlm. 829-61.

2. Blencowe $\mathrm{H}$, Cousens S, Oestergaard MZ, Chou D, Moller A-B, Narwal R, et al. National, Regional, and Worldwide Estimates of Preterm Birth Rates in The Year 2010 With Time Trends Since 1990 for Selected Countries: a Systematic Analysis and Implications. Lancet. 2012;379: :2162-72.

3. Carrie, Shapiro-Mendoza, Lackitz EM. Epidemiology of Late and Moderate Preterm Birth. Semin Fetal Neonat Med. 2012;17:120-5.

4. WHO, PMNCH. Born too soon: the global action report on preterm birth. geneva: World Health Organization; 2012.

5. Hui ASY, Lao TT, Leung TY, Schaaf JM, Sahota DS. Trends in Preterm Birth in Singleton Deliveries in a Hong Kong Population. Int J Gynecol Obstet. 2014;127:248-53.

6. Ananth CV, Friedman AM, GyamfiBannerman C. Epidemiology of Moderate Preterm, Late Preterm and Early Term Delivery. Clin Perinatol. 2013;40:60110.

7. Frey HA, Klebanoff MA. The Epidemiology, etiology, and costs of preterm birth. Semin Fetal Neonat Med. 2016;21:68-73.

8. Kerstjens JM, Winter AFD, BoccaTjeertes IF, Vergert EMJT, Reijneveld SA, Bos AF. Developmental Delay in Moderately Preterm-Born Children at
School Entry. J Pediatr. 2011;159:92-8.

9. Hardy G, Benjamin A, Abenhaim HA. Effect of Induced Abortions on Early Preterm Births and Adverse Perinatal Outcomes. J Obstet Gynaecol Can. 2013;35:138-43.

10. Broek NRVD, Jean-Baptiste R, Neilson JP. Factors Associated with preterm, early preterm and late preterm birth in malawi. Plos One. 2014;9(3).

11. Muglia LJ, Katz M. The Enigma of Spontaneous Preterm Birth. N Engl J Med. 2010;362:529-35.

12. Wijayanegara $\mathrm{H}$, Wirakusumah FF, Krisnadi SR, Mose JC, Sabarudin U, Effendi JS, dkk. Prematuritas. Edisi ke1. Bandung: Reflika Aditama; 2009.

13. Lee J, Kim JS, Park JW, Park CW, Park JS, Jun JK, Yoon BH. Chronic chorioamnionitis is the most common placental lesion in late preterm birth. Placenta. 2013; 681-9

14. McElrath TF, Hecht JL, Dammann O, Boggess K, Onderdonk A, Markenson G, et al. Pregnancy Disorders That Lead to Delivery Before the 28th Week of Gestation: an epidemiologic approach to classification. Am J Epidemiol 2008;168:980-9

15. Lu L, Qu Y, Tang J, Chen D, Mu D. Risk Factors Associated with Late Preterm Births in The Underdeveloped Region of China: A Cohort Study and Systematic Review. Taiwan J Obstet Gynecol. 2015;54 647-53.

16. Hidayat Z, Ajiz EA, Achadiyani, Krisnadi SR. Risk Factor Associated with Preterm Birth at Hasan Sadikin General Hospital in 2015. Open Journal of Obstetric an Gynecology. 2016; 6; 798-806

17. Wijayanegara $\mathrm{H}$, Wirakusumah FF, Krisnadi SR, Mose JC, Sabarudin U, Effendi JS, et al. Panduan Pengelolaan Persalinan Preterm Nasional: Himpunan Kedokteran Fetomaternal POGI; 2012.

18. Manuck TA, Watkins WS, Moore B, 
et al. Pharmacogenomics of 17-alpha hydroxyprogesterone caproate for recurrent preterm birth prevention. Am J Obstet Gynecol. 2014;210:321.e1-21.

19. Frey HA, Stout MJ, Pearson LN, et al. Genetic variation associated with preterm birth in African- American women. Am J Obstet Gynecol. 2016;215:235.e1-8.

20. Zhang Q, Ananth CV, Li Z, Smulian JC. Maternal Anaemia and Preterm Birth: a Prospective Cohort Study. Int J Epidemiol. 2009:;38:1380-9.

21. Ren A, Wang J, Ye R, Li S, Liu J, Li Z. Low first-trimester hemoglobin and low birth weight, preterm birth and small for gestational age newborns. Int $\mathrm{J}$ Gynecol Obstet. 2007;98:124-28.

22. Wang J, Ren A, Ye R, Zheng J, Li S, Liu J et al. Study on the third trimester hemoglobin concentrations and the risk of low birth weight and preterm delivery.
Zhonghua Liu Xing Bing Xue Za Zhi 2007;28:15-18.

23. Ekbom P, Damm P, Rasmussen BF, Rasmussen UF, Jensen DM, Marthiesen ER. Elevated third-trimester haemoglobin A1c predicts preterm delivery in type 1 diabetes. Journal of Diabetes and Its Complications 22 (2008) 297- 302

24. Sahu MT, Das V, Mittal S, Agarwal A, Sahu M. Overt and Subclinical Thyroid Dysfunction Among Indian Pregnant Women and its Effect on Maternal and Fetal Outcome. Arch Gynecol Obstet. 2010;281:215-20.

25. Benhadi N, Wiersinga WM, Reitsma JB, Vrijkotte TGM, Bonsel GJ. Higher Maternal TSH Levels in Pregnancy are Associated with Increased Risk for Miscarriage, Fetal or Neonatal death. Eur J Endocrinol. 2009;160:985-91. 